\section{Dry-matter and Nitrogen Yields of Legumes Interseeded into Sweet Corn}

\author{
Steven J. Guldan ${ }^{1}$ and Charles A. Martin \\ Alcalde Sustainable Agriculture Science Center, New Mexico State University, \\ P.O. Box 159, Alcalde, NM 87511
}

\author{
Jose Cueto-Wong ${ }^{2}$ and Robert L. Steiner ${ }^{3}$ \\ New Mexico State University, Las Cruces, NM 88003
}

Additional index words. multiple cropping, relay intercropping, Vicia villosa, Medicago truncatula, Medicago sativa, Lens culinaris, Trifolium pratense

\begin{abstract}
Five legumes [hairy vetch (Vicia villosa Roth.), barrel medic (Medicago truncatula Gaerth.), alfalfa (Medicago sativa L.), black lentil (Lens culinaris Medik.), and red clover (Trifolium pratense $\mathbf{L}$.)] were interseeded into sweet corn (Zea mays L.) at last cultivation when sweet corn was at about the V9 (early) or blister (late) stage. The effect of legume interseeding on sweet corn yield, and late-season dry-matter and $\mathrm{N}$ yields of aboveground portions of the legumes was determined. Sweet corn yield was not affected by legume interseeding. In 1993, legume dry-matter yields were $1420 \mathrm{~kg} \cdot \mathrm{ha}^{-1}$ interseeded early and $852 \mathrm{~kg} \cdot \mathrm{ha}^{-1}$ interseeded late. Nitrogen yields were $49 \mathrm{~kg} \cdot \mathrm{ha}^{-1}$ interseeded early and 33 $\mathrm{kg} \cdot \mathrm{ha}^{-1}$ interseeded late. In 1994, dry-matter yields were $2760 \mathrm{~kg} \cdot \mathrm{ha}^{-1}$ interseeded early and $1600 \mathrm{~kg} \cdot \mathrm{ha}^{-1}$ interseeded late. Nitrogen yields were $83 \mathrm{~kg} \cdot \mathrm{ha}^{-1}$ interseeded early and 50 $\mathrm{kg} \mathrm{ha}^{-1}$ interseeded late. In 1993, barrel medic was the highest-yielding legume with dry matter at $2420 \mathrm{~kg} \cdot h \mathrm{a}^{-1}$ and $\mathrm{N}$ at $72 \mathrm{~kg} \cdot \mathrm{ha}^{-1}$ interseeded early, while red clover yielded the lowest with dry matter at $340 \mathrm{~kg} \cdot \mathrm{ha}^{-1}$ and $\mathrm{N}$ at $12 \mathrm{~kg} \cdot \mathrm{ha}^{-1}$ interseeded late. In 1994, drymatter and $N$ yields ranged from 4500 and $131 \mathrm{~kg} \cdot \mathrm{ha}^{-1}$, respectively, for early interseeded barrel medic to $594 \mathrm{~kg} \cdot \mathrm{ha}^{-1}$ and $16 \mathrm{~kg} \cdot h \mathrm{a}^{-1}$, respectively, for late interseeded red clover.
\end{abstract}

Legumes have received renewed interest as secondary crops in rotations for soil cover (Gilley et al., 1989; Hargrove and Frye, 1987; Janke et al., 1987; Schonbeck et al., 1993) and green manure (Badaruddin and Meyer, 1990; Schonbeck et al., 1993; Singogo et al., 1991). In the Nebraska study by Gilley et al. (1989), planting date for several legumes significantly affected maximum surface cover and the number of days needed to achieve maximum cover. Studies by Schonbeck et al. (1993) indicated hairy vetch cover crops could potentially reduce $\mathrm{N}$ fertilizer inputs while maintaining production levels of Brassica vegetable crops in the northeastern United States.

Relay intercropping has been defined as a form of multiple cropping in which a second crop is planted into the first crop when the first crop has reached its reproductive stage but before it is harvested (Andrews and Kassam, 1976). Relay intercropping can be used to

Received for publication 29 Aug. 1995. Accepted for publication 22 Dec. 1995. A contribution of the New Mexico Agricultural Expt. Station, New Mexico State Univ., Las Cruces. We gratefully acknowledge the technical assistance of David J. Archuleta and Val S. Archuleta. Use of trade names does not imply endorsement of the products named or criticism of similar ones not named. The cost of publishing this paper was defrayed in part by the payment of page charges. Under postal regulations, this paper therefore must be hereby marked advertisement solely to indicate this fact.

${ }^{1}$ Alcalde Sustainable Agriculture Science Center and Dept. of Agronomy and Horticulture.

${ }^{2}$ Dept. of Agronomy and Horticulture.

${ }^{3}$ Dept. of Experimental Statistics. produce two crops in 1 year in areas where the growing season is too short for sequential or double cropping. A system of relay intercropping beans (Phaseolus spp.) into corn was used by indigenous peoples in the Americas and continues to be a common practice in many parts of Latin America (Pinchinat et al., 1976). Relay intercropping also could be used to insert legume cover crops into rotations that include sweet corn, particularly for producers with small landholdings interested in using land and other on-farm resources as efficiently

Under rain-fed conditions in Pennsylvania, red clover, white clover (T. repens L.), crimson clover ( $T$. incarnatum L.), and hairy vetch interseeded into field corn generally produced more ground cover by fall when interseeded the third week of June vs. the first to second week of July (Janke et al., 1987). In contrast, Austrian winter peas [Pisum sativum subsp.arvense (L.) Poir] germinated well when interseeded in June, but few survived into October, apparently because of their inability to tolerate shading from the corn canopy. In a similar study with field corn in Iowa, Exner and Cruse (1993) found that interseeded alfalfa and yellow sweet clover (Melilotus officinalis Lam.) produced more cover than either red or alsike clover (T. hybridum L.). Success of interseeding legumes in these studies was affected by weather variables, such as amount and time of precipitation as well as legume species tested. Under supplemental irrigation in New York, fall dry-matter yields of alfalfa, red clover, white clover, and ladino clover (T. repens L.) did not differ significantly when interseeded 5 weeks after sweet as possible. corn planting (Vrabel et al., 1980). How hairy vetch, alfalfa, and red clover would perform when relay-intercropped into sweet corn under irrigated conditions in high-desert areas of the southwestern United States is unclear.

Little information is available on using summer annual legumes as a relay intercrop in sweet corn. 'Indianhead' black lentil has recently been developed for use as a green manure. It is frost hardy, and seed is relatively inexpensive compared to other grain legumes (Slinkard et al., 1987). Barrel and other annual Medicago species have been used extensively in southern Australia as pasture legumes in rotation with cereals to improve and maintain soil fertility (Puckridge and French, 1983). Many annual Medicago species are characterized as fast growers that produce large amounts of biomass (Diwan et al., 1994). Given that legumes, such as black lentil and barrel medic, generally produce biomass more rapidly in the first year than perennial legumes, they may be especially suited for relay intercropping into sweet corn. However, a highly competitive legume may have the potential to adversely affect sweet corn yield.

Identifying appropriate legumes for relay intercropping in sweet corn would be particularly beneficial for producers with small landholdings, who need to use land, sunlight, and other on-farm resources as efficiently as possible. Our objectives were to determine the effect of time of legume interseeding on 1) yield of sweet corn and 2) late-season legume aboveground productivity and $\mathrm{N}$ yield.

\section{Materials and Methods}

The experiment was conducted at Alcalde, N.M., on a Fruitland sandy loam [coarseloamy, mixed (calcareous), mesic Typic Torriorthent] during 1993 and 1994. Northrup King 'NK 199' sweet corn was planted on listed beds in rows $91 \mathrm{~cm}$ apart on 25 May 1993 and 9 May 1994. Seeding rate was $\approx 50,000$ seeds/ha. Subplots were four rows wide and $12.2 \mathrm{~m}$ long. Weeds were controlled by a row-crop cultivator and hand weeding. All plots were furrow-irrigated as needed during the season. The first frost of $-2 \mathrm{C}$ or lower, which kills sweet corn, occurred on 20 Oct. 1993 and 10 Oct. 1994

Fertilization was based on soil tests and general New Mexico State Univ. guidelines (Glover and Baker, 1990). Because of the coarse soil texture and use of furrow irrigation, the fertilizer was split into three sidedressings with 1 to 2 weeks between applications. The first occurred at about the first-leaf stage (Ritchie and Hanway, 1984) and consisted of $\mathrm{N}$ and $\mathrm{P}$ at 17 and $28 \mathrm{~kg} \cdot \mathrm{ha}^{-1}$, respectively. Each of the following two applications was $\mathrm{N}$ alone at $56 \mathrm{~kg} \cdot \mathrm{ha}^{-1}$. Nitrogen was in the form of urea, and $\mathrm{P}$ was in the form of triple superphosphate $(20 \%$ P). Each fertilizer was applied in equal amounts on both sides of the row during each sidedressing. Following all sidedressings, plots were cultivated with a two-row cultivator.

Immediately before last cultivation, when plants were at about growth stage V9 (early) 
(Ritchie and Hanway, 1984) and at about the blister stage of the corn (late) (Ritchie and Hanway, 1984), 'Nitro' alfalfa, 'Parabinga' barrel medic, 'Indianhead' black lentil, 'Madison' hairy vetch, and 'Arlington' red clover were hand-broadcast into the standing corn Seeding rates on a pure live-seed basis were (in kg.ha ${ }^{-1}$ ) 16.8 for alfalfa and red clover, 22.4 for barrel medic, 56.0 for black lentil, and 44.8 for hairy vetch. Seed broadcast at the blister stage was lightly worked into the soil with hand rakes. Early interseeding dates were 12 July 1993 and 8 July 1994. Late interseeding dates were 12 Aug. 1993 and 4 Aug. 1994. All legume seed had been inoculated with appropriate Rhizobia before sowing.

The design was a randomized complete block with a split-plot treatment structure and four replications. Main plot treatments were time of legume interseeding, and subplot treatments included legume species and a nolegume control.

Sweet corn was harvested from 31 Aug. to 2 Sept. 1993 and 16 to 17 Aug. 1994 at about the milk stage (Ritchie and Hanway, 1984). Kernel samples from four to six randomly selected ears with kernels at the milk stage were weighed, oven-dried at $65 \mathrm{C}$ for $48 \mathrm{~h}$, and weighed again to determine percent moisture. Kernel moisture at harvest was $\approx 80 \%$ in both years. Harvest samples consisted of combining two 3-m lengths from the middle two rows in each subplot. Stalks were cut $\approx 13 \mathrm{~cm}$ above the soil surface and were removed from the plot. Measurements included fresh weights of aboveground biomass, unhusked ears, and total and marketable husked ears and total and marketable ear counts. Marketable ears consisted of total ear count minus immature ears and ears with insect or bird damage below the tips. Ears with less than $\approx 12 \mathrm{~cm}$ of developed kernels were considered immature. Remaining corn stalks were cut and removed from the plots.

Legumes were harvested on 9 Nov. 1993 and 14 Nov. 1994. Aboveground yields were measured by combining two $0.21-\mathrm{m}^{2}$ subsamples harvested from each subplot. The placement of the square quadrats was such that a representative cross-section of the furrowbed continuum was obtained in each subsample. Samples were oven-dried at $65 \mathrm{C}$ for $48 \mathrm{~h}$, weighed, ground to pass through a $1-\mathrm{mm}$ screen, digested, and analyzed colorimetrically (sodium salicylate-sodium hypochlorite) for total Kjeldahl $\mathrm{N}$ using an autoanalyzer (Technicon Instruments Corp., 1974). Nitrogen yield was obtained by multiplying the drymatter yield by the $\mathrm{N}$ concentration for each legume.

Analysis of variance was performed using the general linear models procedure (SAS Institute, 1992). The 1993 and 1994 data were analyzed separately because variance estimates indicated heterogeneous variances. An F test was used to verify this conclusion.

\section{Results and Discussion}

Sweet corn. Neither legume interseeding time nor legume species significantly $(P>$
0.05) affected any sweet corn yield characteristic. Fresh weight of aboveground biomass averaged $32,400 \mathrm{~kg} \cdot \mathrm{ha}^{-1}$ in 1993 and 24,300 $\mathrm{kg} \cdot \mathrm{ha}^{-1}$ in 1994 . Unhusked ear yield averaged $14,900 \mathrm{~kg} \cdot \mathrm{ha}^{-1}$ in 1993 and 11,000 kg.ha ${ }^{-1}$ in 1994. Marketable yields were severely reduced in 1994 because of bird predation. Fresh weight of marketable ears averaged 8450 $\mathrm{kg} \cdot \mathrm{ha}^{-1}$ in 1993 and $4300 \mathrm{~kg} \cdot \mathrm{ha}^{-1}$ in 1994. Number of marketable ears averaged 39,700 and 26,600 ears/ha in 1993 and 1994, respectively. Similarly, interseeding legumes at last cultivation did not reduce grain yields of field corn (Exner and Cruse, 1993; Palada et al., 1983; Scott et al., 1987). Sweet corn yield was unaffected by interseeding legumes 5 weeks after corn planting (Vrabel et al., 1980).

Legumes. The legume $\times$ interseeding time interaction for legume biomass and $\mathrm{N}$ yields was not significant in either year $(P>0.1)$. Early interseeding generally produced more legume dry-matter and $\mathrm{N}$ yields than late. This difference was highly significant for drymatter yields in both years $(P<0.01)$ and $\mathrm{N}$ yields in $1994(P=0.01)$. In 1993 , the effect was significant for $\mathrm{N}$ yields at $P=0.09$. In that year, lentil $\mathrm{N}$ yields clearly did not follow the trend and were not affected by planting date (Table 1). However, in general, the extra 3.5 to 4.5 weeks of growing period the legumes had available when interseeded early added considerably to legume growth, although this time was characterized by progressively greater shading from the corn canopy as the corn plants approached full size. This result is of practical importance because interseeding, whether done mechanically or manually, would be easier at last cultivation than during kernel development.

Legumes differed in yield for each interseeding time in both years (Table 1). In 1993, barrel medic yielded significantly more than all other legumes except hairy vetch when interseeded early. When interseeded late, hairy vetch yielded significantly more than all other legumes, except barrel medic. In 1994, hairy vetch and barrel medic were the highestyielding legumes whether interseeded early or late. Yields of black lentil, alfalfa, and red clover generally did not differ from each other, except for the late interseeding in 1993 when black lentil yielded more than red clover (Table 1).

When interseeded early, hairy vetch and barrel medic yielded more $\mathrm{N}$ than the other legumes in both years (Table 1). With late interseeding, hairy vetch produced significantly greater $\mathrm{N}$ yields than all other legumes, except barrel medic in 1994 (Table 1). Hairy vetch also yielded more total $\mathrm{N}$ than alfalfa and red clover when seeded after oat harvest (26 July to 5 Aug.) in Wisconsin (Stute and Posner, 1995). The only significant difference among black lentil, alfalfa, and red clover was for the late interseeding in 1993, when black lentil yielded more $\mathrm{N}$ than red clover (Table 1).

The results indicate that barrel medic could be particularly useful as an interseeded legume in sweet corn if high late-season legume biomass, $\mathrm{N}$ content, or forage production is a goal. Clearly, barrel medic was more productive than the perennial types used in this study as well as the other summer annual black lentil; it also was more productive than hairy vetch for the early (and most practical) interseeding time, although these differences were not significant statistically in either year. Importantly, barrel medic also did not reduce sweet corn yields.

The amount of $\mathrm{N}$ accumulated by early interseeded barrel medic and hairy vetch, in the range of 70 to $130 \mathrm{~kg} \cdot \mathrm{ha}^{-1}$, could contribute toward meeting the $\mathrm{N}$ needs of a subsequent crop. Nitrogen recovery by the subsequent crop, however, may vary depending on soil type, crops, environmental conditions, or management factors.

Relay intercropping is a way to insert legumes into intensive sweet corn rotations in the high-desert region of the southwestern United States. Interseeding the legumes at last cultivation of the sweet corn resulted in higher legume dry-matter and $\mathrm{N}$ yields than interseeding at the blister stage of sweet corn. Of the legumes tested, barrel medic and hairy vetch were the most productive in terms of aboveground dry-matter and $\mathrm{N}$ yields.

Table 1. Aboveground dry-matter and $\mathrm{N}$ yields of legume species following two interseeding dates in sweet corn.

\begin{tabular}{|c|c|c|c|c|}
\hline \multirow[b]{3}{*}{ Legume } & \multicolumn{4}{|c|}{ Interseeding date $^{\mathrm{z}}$} \\
\hline & \multicolumn{2}{|c|}{1993} & \multicolumn{2}{|c|}{1994} \\
\hline & $\begin{array}{c}\text { Early } \\
\text { (12 July) }\end{array}$ & $\begin{array}{c}\text { Late } \\
\text { (12 Aug.) }\end{array}$ & $\begin{array}{c}\text { Early } \\
\text { (8 July) }\end{array}$ & $\begin{array}{c}\text { Late } \\
\text { (4 Aug.) }\end{array}$ \\
\hline \multicolumn{5}{|c|}{ Dry wt $\left(k g \cdot h a^{-1}\right)$} \\
\hline Madison hairy vetch & $1780 a b^{y}$ & $1450 \mathrm{a}$ & $3810 \mathrm{a}$ & $2790 \mathrm{a}$ \\
\hline Parabinga barrel medic & $2420 \mathrm{a}$ & $1010 \mathrm{ab}$ & $4500 \mathrm{a}$ & $2320 \mathrm{a}$ \\
\hline Indianhead black lentil & $990 \mathrm{~b}$ & $923 \mathrm{~b}$ & $2170 \mathrm{~b}$ & $1060 \mathrm{~b}$ \\
\hline Nitro alfalfa & $1090 \mathrm{~b}$ & $533 \mathrm{bc}$ & $1470 \mathrm{~b}$ & $1210 \mathrm{~b}$ \\
\hline Arlington red clover & 816 b & $340 \mathrm{c}$ & $1850 \mathrm{~b}$ & 594 b \\
\hline \multicolumn{5}{|c|}{$N$ yield $\left(k g \cdot h a^{-1}\right)$} \\
\hline Madison hairy vetch & $70 \mathrm{a}$ & $58 \mathrm{a}$ & $124 \mathrm{a}$ & $88 \mathrm{a}$ \\
\hline Parabinga barrel medic & $72 \mathrm{a}$ & $37 \mathrm{~b}$ & $131 \mathrm{a}$ & $69 \mathrm{ab}$ \\
\hline Indianhead black lentil & $34 b$ & $35 \mathrm{~b}$ & $58 \mathrm{~b}$ & $34 \mathrm{c}$ \\
\hline Nitro alfalfa & $41 \mathrm{~b}$ & $21 \mathrm{bc}$ & $53 \mathrm{~b}$ & $43 \mathrm{bc}$ \\
\hline Arlington red clover & $29 \mathrm{~b}$ & $12 \mathrm{c}$ & $49 \mathrm{~b}$ & $16 \mathrm{c}$ \\
\hline
\end{tabular}

${ }^{\mathrm{z}}$ Early $=$ last cultivation of sweet corn; late = blister stage of sweet corn.

y Mean separation within columns by Duncan's multiple range test at $P \leq 0.05$. 


\section{Crop Production}

\section{Literature Cited}

Andrews, D.J. and A.H. Kassam. 1976. The importance of multiple cropping in increasing world food supplies, p. 1-10.In: R.I.Papendick, P.A. Sanchez, and G.B. Triplett (eds.). Multiple cropping. Amer. Soc. Agron. Spec. Publ. 27, Madison, Wis.

Badaruddin, M. and D.W. Meyer. 1990. Greenmanure legume effects on soil nitrogen, grain yield, and nitrogen nutrition of wheat. Crop Sci. 30:819-825.

Diwan, N., G.R. Bauchan, and M.S. McIntosh. 1994. A core collection for the United States annual Medicago germplasm collection. Crop Sci. 34:279-285.

Exner, D.N. and R.M. Cruse. 1993. Interseeded forage legume potential as winter ground cover, nitrogen source, and competitor. J. Production Agr. 6:226-231.

Gilley, J.E., J.F. Power, P.J. Reznicek, and S.C. Finkner. 1989. Surface cover provided by selected legumes. Applied Eng. Agr. 5:379-385.

Glover, C.R. and R.D. Baker. 1990. Fertilizer guide for New Mexico. New Mexico State Univ. Coop. Ext. Serv. Guide A-128.

Hargrove, W.L. and W.W. Frye. 1987. The need for legume cover crops in conservation tillage production, p. 1-5. In: J.F. Power (ed.). The role of legumes in conservation tillage systems. Proc. Soil Conservation Soc. Amer. Natl. Conf., Athens, Ga., 27-29 Apr. 1987.
Janke, R.R., R. Hofstetter, B. Volak, and J.K. Radke. 1987. Legume interseeding cropping systems research at the Rodale Research Center, p. 9091. In: J.F. Power (ed.). The role of legumes in conservation tillage systems. Proc. Soil Conservation Soc. Amer. Natl. Conf., Athens, Ga., $27-$ 29 Apr. 1987.

Palada, M.C., S. Ganser, R. Hofstetter, B. Volak, and M. Culik. 1983. Association of interseeded legume cover crops and annual row crops in year-round cropping systems, p. 193-213. In: W. Lockeretz (ed.). Environmentally sound agriculture. Proc. 4th Intl. Conf. Resource Conserving, Environmentally Sound Agr. Alternatives, Cambridge, Mass., 18-20 Aug. 1982.

Pinchinat, A.M., J. Soria, and R. Bazan. 1976. Multiple cropping in tropical America, p. 5161. In: R.I. Papendick, P.A. Sanchez, and G.B. Triplett (eds.). Multiple cropping. Amer. Soc. Agron. Spec. Publ. 27, Madison, Wis.

Puckridge, D.W. and R.J. French. 1983. The annual legume pasture in cereal-ley farming systems of southern Australia: A review. Agr., Ecosystems \& Environ. 9:229-267.

Ritchie, S.W. and J.J. Hanway. 1984. How a corn plant develops. Spec. Rpt. 48. Coop. Ext. Serv., Iowa State Univ., Ames.

SAS Institute. 1992. SAS user's guide. SAS Inst., Cary, N.C.

Schonbeck, M., S. Herbert, R. DeGregorio, F. Mangan, K. Guillard, E. Sideman, J. Herbst, and
R. Jaye. 1993. Cover cropping systems for Brassicas in the northeastern United States: 1. Cover crop and vegetable yields, nutrients and soil conditions. J. Sustainable Agr. 3(3/4):105-132.

Scott, T.W., J. Mt. Pleasant, R.F. Burt, and D.J. Otis. 1987. Contributions of ground cover, dry matter, and nitrogen from intercrops and cover crops in a corn polyculture system. Agron. J. 79:792798.

Singogo, W., W.J. Lamont, Jr., and C.W. Marr. 1991. Legumes alone and in combination with manure as fertilizers in an intensive muskmelon production system. HortScience 26:1431.

Slinkard, A.E., V.O. Biederbeck, L. Bailey, P. Olson, W. Rice, and L. Townley-Smith. 1987. Annual legumes as a fallow substitute in the northern Great Plains of Canada, p. 6-7. In: J.F. Power (ed.). The role of legumes in conservation tillage systems. Proc. Soil Conservation Soc. Amer. Natl. Conf., Athens, Ga., 27-29 Apr. 1987.

Stute, J.K. and J.L. Posner. 1995. Legume cover crops as a nitrogen source for corn in an oat-corn rotation. J. Production Agr. 8:385-390.

Technicon Instruments Corp. 1974. Ammoniacal nitrogen/BD acid digests. Industrial method 32174A. Technicon Instruments Corp., Tarrytown, N.Y.

Vrabel, T.E., P.L. Minotti, and R.D. Sweet. 1980. Seeded legumes as living mulches in sweet corn. Paper 769, Dept. of Vegetable Crops, Cornell Univ., Ithaca, N.Y. 